\title{
Retraction Note: Nicotiana tabacum Tsip1-Interacting Ferredoxin 1 Affects Biotic and Abiotic Stress Resistance
}

\author{
Sung Un Huh ${ }^{1,3}$, In-Ju Lee ${ }^{1}$, Byung-Kook Ham ${ }^{2}$, and Kyung-Hee Paek ${ }^{1, *}$ \\ Retraction Note: Mol. Cells 34 (2012) 43-52 \\ DOI/10.1007/s10059-012-0066-6
}

Members of the editorial board have un-animously agreed to retract the article DOI/10.1007/s10059-012-0066-6 [Mol. Cells 34 (2012) 43-52] for potential misconducts mainly concerning manipulation and repeated uses of hotomicrographs of control data internally along with mislabeling and/or externally in multiple publications. As specified in the "Instructions to Authors", Molecules and Cells (Mol. Cells) explicitly prohibits mis-representation or falsification of experimental data including duplication of previously published data. In the article, photomicrographs in Fig. S3A have been previously published in Plant Cell Physiol. 45 (2004) 1537-1542, Plant Mol. Biol. 59 (2005) 981994, Plant Cell Rep. 25 (2006), 359-364, Biochem. Biophys. Res. Commun. 339 (2006) 399-406, and Biochem. Biophys. Res. Commun. 340 (2006), 228-235.

${ }^{1}$ School of Life Sciences and Biotechnology, Korea University, Seoul 136-701, Korea, ${ }^{2}$ Section of Plant Biology, College of Biological Sciences, University of California, California 95616, USA, ${ }^{3}$ Present address: Jeju Biodiversity Research Institute, Jeju 699-943, Korea

${ }^{*}$ Correspondence: khpaek95@korea.ac.kr 